\title{
BRUNON BARTZ
}

E-MAIL: B.BARTZ@MIECERTJA.EU

\section{REALIA EUROPEJSKIEJ POLITYKI GRANICZNO- -MIGRACYJNEJ. KULTURA PRZYJMOWANIA I INKLUZJI MIGRANTÓW}

\section{Wprowadzenie}

Europejska polityka migracyjna jest równocześnie kompleksowym i dynamicznym obszarem nauki o interdyscyplinarnym profilu. Opiera się ona formalnie na Deklaracji Praw Człowieka (z 10.12.1948 roku), Konwencji Uchodźców ONZ i Europejskiej Konwencji Praw Człowieka. Wolność ruchu osobowego, podejmowania pracy i osiedlania się obywateli i imigrantów na obszarze Unii Europejskiej (UE) w wybranym kraju oficjalnie są uznawane za wartości oczywiste. Te wzniosłe humanitarnie akta prawne nie uwzględniły jednakże skali ruchu migracyjnego, jej okresowego impetu oraz dramatów, jakie przeżywają uchodźcy, jako nieregularni migranci, przy przekraczaniu granic państwowych. W respektowanie humanitarnych wartości w wielu krajach UE można wątpić, jeżeli na ich granicach lub bezpośrednio przed nimi giną dziesiątki tysięcy uchodźców. Stąd określenie takiej polityki w tytule tego artykułu graniczno-migracyjną, ponieważ de facto jest ona skoncentrowana na ochronie granic przed usiłującymi je nielegalnie przekraczać migrantami, a nie ich sprawną integracją lub inkluzją w społeczeństwach, które ich potrzebują, ze względu na europejską katastrofę demograficzną, powtarzające się recesje i wydatny wkład w rozkład cywilizacji zachodniej. Polityka ta od początku istnienia Wspólnoty Europejskiej, a potem Unii Europejskiej jest niejednolita w sensie humanitarnym, politycznym i prawnym oraz niezwykle kontrowersyjna w rozumieniu naukowym, kulturowym i ekonomicznym. Postaram się uzasadnić na podstawie faktów, jak i gdzie odmawia się godności i respektu imigrantom, którzy przybyli do Europy, by uciec od biedy, represji i wojny w poszukiwaniu pracy i możliwości samorealizacji, a spotkali się z niechęcią, nieżyczliwością i nieludzkim traktowaniem. Przedstawię też koncepcję naprawy procesu integracji imigrantów, uwzględniającej dorobek współczesnej 
nauki w przezwyciężaniu impasu w wielokulturowym porozumieniu. $\mathrm{Na}$ świecie egzystuje ponad 10 tys. grup etnicznych (ludów), [Theisen 2009: 8], z których każda dysponuje swoją kulturą i mieszczą się one w 230 państwach. Świadczy to, że wszystkie państwa są wielokulturowe. W Europie na 45 państw przypada 90 kultur odwiecznych i setki przetransferowanych przez migrantów, co potwierdza stan jej wielokulturowości, od którego nie ma żadnego odwołania. Porozumienie między przedstawicielami tych kultur staje się dlatego kluczowym czynnikiem i szansą rozwoju naszego kontynentu.

\section{Migracja w skali globalnej i europejskiej}

Według Wydziału Biura Ludności ONZ do spraw Gospodarczych i Społecznych (DESA), [Alscher 2013] udział migrantów wśród ludności świata wzrósł od roku 1990 (2,9\%) do roku 2012 o 3,2\%. Ponieważ w tym samym czasie ludność świata przyrosła z 5,3 do 7,1 mld, liczba absolutna migrantów wzrosła do $232 \mathrm{mln}$ (w roku 2000 było ich $175 \mathrm{mln}$ ) i osiągnęła najwyższy stan w historii. Międzynarodowa Organizacja Migracji (IOM) rozróżnia cztery kierunki globalnego ruchu migracyjnego i w tym podziale przeprowadziła - w porozumieniu $\mathrm{z}$ wymienioną agendą ONZ - analizę subiektywnego poczucia migrantów dotyczącą finansowego dobrobytu, szans zrobienia kariery, bezpieczeństwa w zachowaniu zdrowia, wspólnoty z tubylcami i społecznej partycypacji. Pytano migrantów, w jakim stopniu ich emigracja przyczyniła się do poprawy ich sytuacji w wymiarze indywidualnym i rodzinnym. Odpowiedzi migrantów porównano następnie z wypowiedziami ludności krajów docelowych i pochodzenia odrębnie w czterech kierunkach:

- Kierunek Północ > Północ: na obszarze północnej półkuli migracja obejmuje $22 \%$ światowej populacji migrantów. Migranci osiągają dość szybko podobne poczucie jak ludność docelowego kraju, a w wielu przypadkach uzyskują nawet wyższy standard życiowy.

- Kierunek Południe > Północ: migranci na tym obszarze stanowią $40 \%$ wszystkich migrantów. Osiągają oni wprawdzie lepsze warunki niż doświadczali w swoich krajach pochodzenia, ale mają trudności z poszukiwaniem pracy i osiągają niższe wynagrodzenie aniżeli ludność kraju docelowego. W zdrowiu i jego zabezpieczeniu dochodzą do tych samych parametrów jak ludność miejscowa. 
- Kierunek Północ > Południe: udział migrantów z północnej do południowej półkuli naszego świata obejmuje zaledwie 5\% całego ruchu migracyjnego. Kto decyduje się na taką emigrację odczuje, wskutek dużych szans integracji na rynku pracy i niższego poziomu cen, przyrost osobistej siły popytu. Z drugiej strony, mogą się liczyć $\mathrm{z}$ niezadowoleniem i zgrożeniami w obszarze osobistego bezpieczeństwa, poziomu służby zdrowia i ograniczeniami w społecznej partycypacji.

- Kierunek Południe > Południe: obszar półkuli południowej globu obejmuje 33\% całego ruchu migracyjnego. Migranci tego kierunku muszą się liczyć z najmniejszymi osobistymi korzyściami i największymi problemami. Tylko 53\% tych migrantów oceniło ich poczucie zadowolenia jako zadowalające, wobec 73\% ludności kraju docelowego.

\section{Znaczenie ruchu migracyjnego}

Sekretarz Generalny ONZ Kofi Annan powołał w 2003 roku Komisję Globalną do spraw Międzynarodowej Migracji, która zajęła się wszechstronną problematyką tego zjawiska i doszła do wniosku końcowego, odmiennie traktującego dotychczasowe negatywne mniemanie o migracji. Jest to nowy paradygmat, który jednoznacznie określa migrację jako zjawisko pozytywne zarówno dla samego migranta, jak również dla długotrwałych interesów kraju emigracyjnego i imigracyjnego. Do uregulowania współżycia w fazie intensyfikacji współczesnej wielokulturowości, implikowanej przez wzmożony ruch migracyjny, przysłużył się też Parlament Światowych Religii obradujący w Chicago (1993 rok), który opracował i uchwalił zasady rozwiązań i modeli współżycia w polietnicznym kontekście, nazywając je pryncypiami światowego etosu (ŚE), [Council... 1993]. Mają one wymiar globalny, więc nadają się na kanwę dla kształtowania pokojowego współżycia w metropoliach i krajach imigracyjnych.

Rozwój i postęp na świecie w ogóle zawdzięczamy międzykulturowej wymianie informacji i wartości. Tak było zawsze, tak jest tym bardziej dzisiaj, w dobie globalizacji. Migranci w swej masie transferują do innych kultur cały posiadany potencjał, starają się go zastosować w nowym kraju, ale nie zapominają o swoim kraju rodzinnym i - o ile to możliwe - wspomagają go w różnych formach. Przykładów korzyści z migracji jest bardzo 
wiele. Przytoczę kilka. Dane o przekazywaniu pieniędzy przez migrantów do swoich krajów rodzinnych według Banku Światowego [The World Bank... 2006] są imponujące i wręcz zadziwiające. Kiedy w roku 2001 przelali oni 75 mld dolarów, to w roku 2005 już 232 mld dolarów. W tym czasie światowa pomoc dla krajów rozwijających wyniosła 79 mld dolarów. Głównymi odbiorcami tych przekazów w roku 2004 były takie kraje, jak Meksyk (16 mld), Indie (9,9 mld), Filipiny (8,5 mld). Licząc jednakże procentowy odsetek tych przelewów w stosunku do PKB, najwięcej zyskały kraje małe, takie jak Togo (37\%), Lesoto (27\%) i Jordania (23\%). Fakty te, a zwłaszcza wynikające z nich korzyści w zwalczaniu biedy i niedostatków służby zdrowia, przyczyniają się stopniowo do zmiany myślenia o migrantach. Dziś kojarzy się migrację coraz częściej z rozwojem. Stare doktryny polityczne, polegające na unikaniu i ograniczaniu prądów migracyjnych przez bilateralną i multilateralną pomoc rozwojową, odchodzą do lamusa. Lapidarnie ujmując, pomoc ta trafiała często do źle zarządzanych państw, skorumpowanych elit, a jeśli częściowo podlegała podziałowi, nie dochodziła do najbardziej poszkodowanej ludności. W takich okolicznościach migranci stali się najwłaściwszymi partnerami dla polepszenia bytu ludzi w krajach emigracyjnych. Jest to de facto zmiana przeważającego dotychczas paradygmatu podejścia do migrantów i całego ruchu migracyjnego. Co jednak jest nadzwyczaj kłopotliwe, to liczne przykłady świadczące o tym, iż dowody o zaletach migracji, a zwłaszcza szansa zwalczania przy jej pomocy przyczyn biedy czy trwałego przyśpieszenia transferu nowoczesności nie zmienia $\mathrm{w}$ większości krajów świata, w tym w wielu krajach europejskich, ujemnego stosunku do migrantów. Odmawia się im często uprawnień ustalonych w Ogólnej Deklaracji Praw Człowieka, uchwalonej przez ówczesnych członków ONZ. Tymczasem prawa te chronią wszystkich ludzi, bez względu na ich psychofizyczne cechy, poglądy, wyznawaną wiarę, czy kraj lub kulturę pochodzenia. „W ostateczności, tzw. nielegalni migranci, którzy przekraczają granicę do innego kraju tzw. zieloną drogą, wbrew przepisom państwowym, bez osobistych dokumentów, nie stają się przecież nielegalnymi ludźmi, gdyż takowych, ani w sensie filozoficznym, ani tym bardzie prawnym być nie może". W sprawozdaniu Komisji Globalnej ONZ stwierdza się m.in., że

ponad 50\% migrantów w Europie pracuje, przyczyniając się do wytworzenia w poszczególnych krajach docelowych produktu krajowego brutto (PKB) o wartości dziesiątek miliardów dolarów. W latach 1999-2000 to nie kto inny, lecz migranci byli odpowiedzialni za 89\% przyrostu demograficznego w Euro- 
pie. Bez migracji ludność naszego kontynentu zmalałaby w okresie pięcioletnim o 4,4 mln ludzi. W roku 2004 ci sami migranci wzbogacili swoje kraje rodzinne, wysyłając drogą bankową 150 mld \$ (co stanowi kwotę trzykrotnie większą, aniżeli wynosi światowa pomoc dla krajów rozwijających się), a innymi drogami dodatkowo 300 mld \$ [Brinkbaeumer 2006 nr 26].

Kiedy w roku 2013 zgłosiło się do ONZ 69 państw, oznajmiając, że znajdują się w stanie kryzysu gospodarczego, w roku 2012 zarejestrowano na świecie 45,2 mln uchodźców, czyli takich migrantów, którzy wyemigrowali ze swoich krajów macierzystych w sposób nieformalny. Było ich najwięcej od 1994 roku. Prawie 55\% wszystkich uchodźców przybyło tylko z 5 krajów: Afganistanu, Somalii, Iraku, Syrii i Sudanu (48\% wszystkich uchodźców to kobiety, a 46\% to dzieci). Z przyczyn zachowania bezpieczeństwa, gospodarczych i politycznych rozszerza się na świecie kontrolę migracji tak, by móc odróżnić migrantow i migrantki, których(e) poszczególne państwa sobie „życzą"lub „nie życzą“. Do tych ostatnich zalicza się także nieregularnych migrantów. Jak wiadomo, istnieją na świecie co najmniej dwie wykładnie interpretacji statusu migrantów. Państwa, w tym członkowie Unii Europejskiej, traktują osoby przekraczające granice państwowe bez ważnych dokumentów (dowodu lub paszportu i wizy) jako migrantów nielegalnych, a ONZ jako nieregularnych. W słownictwie prawnym ONZ nie używa się bowiem określenia „nielegalny migrant“, gdyż oznaczałoby to, że jest to „nielegalny człowiek“, a tak być nie może (gdyż jest to nielogiczne i niegodne), ponieważ każdy człowiek jest legalny. Ponadto, od dłuższego czasu ustalone przez Konwencję Uchodźców ONZ (z 28 lipca 1951 roku) prawo zobowiązujące do udzielania uchodźcom azylu, jest przez wiele państw ograniczane i tym samym ich ochrona poważnie redukowana. Dotarcie do bezpiecznego państwa - szczególnie należącego do UE - i rozpoczęcia w nim nowego życia, staje się dla uchodźców coraz trudniejsze. Zabezpieczenie granic ma dzisiaj pierwszeństwo przed ochroną uchodźców. Udowadnia to wiele przypadków deportacji i ponad 20 tys. wypadków śmierci przy usiłowaniu przekraczania zewnętrznych granic UE od 1990 roku.

Ponad $80 \%$ wszystkich migrantów żyje w krajach rozwijających się i mniej niż $20 \%$ w krajach rozwiniętych, przy czym dziesięć lat temu było ich jeszcze 30\%. Większość uchodźców pochodzi z krajów ubogich i miejsce swojej emigracji znajdują oni także w innych biednych krajach.

W roku 2012 żyło w UE 1,5 mln uchodźców. Tylko 479300 z 7,6 mln nowych uchodzców złożyło wnioski o azyl w krajach rozwiniętych, w tym 297000 
w UE. Było to $4 \%$ populacji wszystkich szukających prawnej ochrony, w tym $25 \%$ kobiet i $20 \%$ niepełnoletnich. Tymczasem w roku 2012 rozwinięte państwa zadeklarowały 172000 i UE 5500 miejsc dla nowo przybywających uchodźców. W taki oto sposób globalna Północ, łącznie z UE, mniej lub bardziej skutecznie pozbawia się uchodźców z globalnego Południa, zwłaszcza kobiet i dzieci. Koszty takiego traktowania ponoszą przede wszystkim sami uchodźcy i docelowe państwa, ktore ich przyjęły lub do których zostali wydaleni” [por. European Council... 2012].

Pozytywnym wyjątkiem w tym nieprzychylnym scenariuszu postępowania są Niemcy. Wraz z piątą rundą przyjęcia nowych państw w 2007 roku (akcesja Bułgarii i Rumunii) liczba państw członkowskich wzrosła do 27, ale zarazem powiększył się dystans w poziomie dobrobytu. Produkt krajowy brutto (PKB) w przeliczeniu na jednego mieszkańca w tych nowo przyjętych krajach stanowił tylko $47 \%$ przeciętnej pozostałych krajów Unii Europejskiej. Liczba migrantów bułgarskich przybyłych np. do Niemiec zwiększyła od 46 tys. (w roku 2007) do 118 tys. (w roku 2012), a rumuńskich od 85600 (w roku 2007) do 205 tys. (w roku 2012). Niemiecką opinię publiczną nie tyle poruszyła imigracja z tych krajów jako taka, gdyż kraj ten stał się formalnie imigracyjnym od roku 2005, lecz równoległa wzmożona fala migracyjna $\mathrm{z}$ innych regionów świata, która osiągnęła w 2012 roku liczbę 589700 osób i określona została jako „Armutsmigration” (czyli „migracja biedy”). Ponad 50 tys. z nich złożyło wniosek o azyl, co, oprócz Francji, należy do najwyższej liczby w Unii Europejskiej. W roku 2013 Niemcy przyjęły dodatkowo ponad 5 tys. uchodźców z Syrii, 2500 z Libanu i 200 z Tunezji. Większość bowiem przybyszów obciążyła fundusze socjalne landów i gmin, ponieważ nie mogli oni podjąć pracy bez znajomości języka i przejścia procedury uzyskania statusu azylanta lub wnioskującego pozwolenie na pobyt stały.

Najnowsza sytuacja migrantów uzasadnia, niestety, negatywną generalizację polityki migracyjnej w wymiarze globalnym i europejskim, ze wskazaniem na tę ostatnią.

\section{Przyjmowanie uchodźców w granicach Unii Europejskiej}

Wprawdzie we wszystkich państwach członkowskich działają dostosowane do prawa UE narodowe ustawy, ale ich zastosowanie w praktyce jest bardzo zróżnicowane i uzależnione w dużym stopniu od kultury or- 
ganizatorskiej i prawnej, a także od przebiegu procesu ustalania tożsamości i ogólnej atmosfery publicznej. Na przykład kwoty uznania wniosków o azyl w 2007 roku wahały się w granicach od 2,7\% w Grecji, przez 35\% w Niemczech do 61,2\% we Włoszech. Czas oczekiwania na przyznanie azylu lub zezwolenia na pobyt, czyli okres niepewności, trwał zwykle długo (na Cyprze do 12 lat). Odpowiedzialna w roku 2013 za politykę migracyjną UE Komisarz - Pani Anna Malmstroem - stwierdziła, że system udzielania azylu w UE jest „taki jak w «loterii»”. W niektórych krajach ochrony uchodźców odmawia się już przy nielegalnym przekraczaniu granicy, jeżeli bezpośrednie przesiedlenia następują do tzw. państw trzecich, znanych $\mathrm{z}$ negatywnego stosunku do tego rodzaju przybyszów. Czynią to Węgry, wydalając migrantów do Ukrainy i Serbii, Grecja do Turcji i Włochy do Libii. Ci, których się, mimo perturbacji granicznych, przyjmie, zatrzymuje się w specjalnych obozach nadzorowanych przez policję (np. w Polsce przez 2, na Węgrzech przez 6 i na Malcie przez 12 miesięcy). W Grecji, Polsce i na Malcie są zatrzymywane także rodziny i dzieci. Są to jednoznaczne pogwałcenia artykułu 5 Europejskiej Konwencji Praw Człowieka normującej prawo migranów do wolności i bezpieczeństwa. W latach 2010-2011 Malta i Węgry za nieprzestrzeganie wymienionej Konwencji zostały osądzone i ukarane. Nie ma jednak informacji, czy dotknięci migranci otrzymali stosowną rekompensatę, co dopiero stanowiłoby przynajmniej częściowe zadośćuczynienie za przeżyte udręki.

Po zakończeniu okresu formalnego zatrzymania, migranci z reguły przesiedlani są tymczasowo do tzw. obozów otwartych (Malta, Węgry, Włochy, Słowacja).Warunki w tych obozach są krytyczne; najczęściej narzeka się na brak prywatnej sfery migrantów, gdyż są oni lokowani w pofabrycznych halach i magazynach o dużej liczbie łóżek, niedostatecznym umeblowaniu i niedostosowanych sanitariatach. Najczęściej brakuje też dostępu do służby zdrowia i obsługi prawnej, a całością zarządza zły albo w ogóle niewykwlifikowany personel. Dlatego właśnie członkowie Rady Europy kontrolujący obozy w Grecji w ramach Komitetu do spraw Przeciwdziałania Torturom określili panujące tam warunki jako „nieludzkie i poniżające“.

W większości państw UE, po opuszczeniu przez uchodźców ostatniego obozu, nie pomaga się im w ogóle lub niekiedy tylko na czas określony, np. w otrzymaniu lokalu mieszkalnego. Na prywatnym rynku mieszkaniowym odmawia się im lokalu ze względu na dyskryminację ze strony właścicieli i niechętnej postawy niektórych mieszkańców. W następstwie tej sytuacji wiele rodzin migranckich, razem z dziećmi staje się bezdomnymi, którzy urządzają się z konieczności na obrzeżach miast, w parkach lub 
przyczyniają się niechcący do przepełniania lokali krewnych i znajomych. Najczęściej zdarza się to w Grecji, Polsce, na Węgrzech i we Włoszech, Problem ten wzmacnia jeszcze fakt, że po wyjściu z obozu migranci moga liczyć tylko na niewielkie świadczenia socjalne (na Węgrzech - 90 euro miesięcznie, maksymalnie przez 2 lata), co nie wystarcza na czynsz nawet najtańszego mieszkania. We Włoszech nie wypłaca się takim migrantom żadnych świadczeń. Ponadto obowiązuje przepis, że jeśli ktoś nie może wynająć mieszkania i nie przedstawi dokumentu o zameldowaniu, nie jest uprawniony do świadczeń socjalnych (w tym zdrowotnych). Powstało w ten sposób diabelskie koło, którego nie można opanować nawet w krajach o rzekomo wysokiej kulturze.

Do mankamentow wynikających z wykluczenia i bezbronności uchodźców należą ekscezy gwałtów popełnianych w obozach przez wartowników (Grecja, Wegry) lub przez rasistów na ulicach (Grecja, Węgry, Włochy). Migranci donoszą ponadto, że często głodują, gdyż stać ich tylko na jeden posiłek dziennie. Dlatego zapadają na choroby spowodowane brakiem odpowiedniego wyżywienia, a te pociągają za sobą konieczność kupowania leków, na które nie mają pieniędzy (Grecja, Węgry, Włochy). Do najtrudnieszych kwestii należą długotrwałe problemy ze znalezieniem pracy. We Włoszech dokumenty wykształcenia nie są uznawane (chyba, że się za tę czynność specjalnie zapłaci).Urzędy pracy nie pomagają w poszukiwaniu miejsca zatrudnienia. Poradnictwo psychologiczne dla migrantów będących ofiarami wojny i prześladowań jest niezwykle trudne do osiągnięcia. Dzieciom i młodzieży nie gwarantuje się uczęszczania do szkoły i dorosłym nie proponuje ani kursów językowych, ani zawodowych (Węgry, Włochy). We wszystkich krajach niepaństwowe organizacje charytatywne i społeczne oferują wprawdzie różne usługi integracyjne i w pojedynczych przypadkach są one bardzo przydatne i skuteczne, ale nie mogą przecież zastąpić systemowego niedosytu w funkcjonowaniu instytucji państwowych na rzecz sprawnej inkluzji migrantów do świata pracy lub instytucji zbezpieczenia socjalnego.

W polityce i przepisach UE przybycie uchodźcy bez wizy skodyfikowano jako „niedozwolone przekroczenie granicy“, do którego niedopuszczenia są zobowiązane wszystkie państwa członkowskie. Uchodźcom może, ale nie musi być „przyznane pozwolenie na wjazd (do wybranego kraju) z powodów humanitarnych lub z powodów narodowego interesu i międzynarodowych zobowiązań”. Prawnego zobowiązania do przyjęcia uchodźcy, np. zgodnie z Konwencją Uchodźców ONZ, nie ma. Obowiązek wizowy, obowiązek do dozorowania granic i brak obowiązku ochrony uchodźców 
to najistotniejsze reguły ustawowe, które powinny zniechęcić uchodźców do zamiaru przekroczenia granicy UE i ustawowo - ale koniecznie de facto - zobowiązać do pozostawania w krajach poza Unią Europejską. Gdyby jednak udało się im nielegalnie znaleźć na obszarze UE i złożyć wniosek o azyl, nie mogą być wydaleni do państwa niebędącego członkiem Unii Europejskiej.

Dodatkowym ograniczeniem dowolnego poruszania się uchodźców po obszarze UE jest przepis Rady Europejskiej (tzw. Dublin-II-Konwencji z 18.02.2003 roku), zobowiązujący do przeprowadzenia przewodu o otrzymanie azylu w pierwszym kraju UE, do którego dany uchodźca przybył. Sens artykułu 10, ustęp 1, tego przepisu jest nastepujący: jeżeli uchodźca przekroczył granicę państwa członkowskiego UE nielegalnie, to państwo to jest odpowiedzialne za sprawdzenie wniosku o azyl tego uchodźcy. Gdyby jednak udało się uchodźcy z krajów południowych lub wschodnich UE dotrzeć do krajow północnych lub zachodnich UE, po ujawnieniu tego faktu będzie on odesłany do tego kraju UE, którego granicę przekroczył po raz pierwszy. Dlatego regulacja ta stanowi w rzeczywistości karę dla państwa położonego na peryferiach UE, gdyż nie potrafiło ono przeszkodzić nielegalnemu przekroczeniu granicy.

Wbrew wzniosłym wartościom moralnym (również chrześcijańskim jak np. "gość w dom, Bóg w dom”) w UE istnieją możliwości ekspresowego uzyskania statusu obywatela w niektórych państwach członkowskich, wystarczy tylko spełnić pewne warunki materialne lub osobowe [Bruegmann i in. 2014]. W kraju nadbałtyckim - Łotwie (państwie grupy Schengen) można otrzymać prawo do 5-letniego pobytu, a potem obywatelstwa, po wpłacie do łotewskiego przedsiębiorstwa 38 tys. euro lub po zakupie nieruchomości w Rydze za 75 tys. euro. Na Węgrzech otrzymuje się status rezydenta za 250 tys. euro, co dostępne jest również w Grecji za zakup nieruchomości w tej samej cenie. Na błyskawiczne wydanie dowodu osobistego mogą liczyć chętni skądkolwiek pochodziliby w Bułgarii (za zainwestowanie w "priorytetowe projekty“ $0,5 \mathrm{mln}$ euro) i na Malcie (za wpłatę gotówki w wysokości 650 tys. euro lub zakup nieruchomości za 350 tys. euro albo zakup maltańskich akcji za 150 tys. euro na 5 lat). W Portugalii, gdzie sprzedawano „złote wizy“, czyli obywatelstwa za zainwestowanie 0,5 mln euro, zgłaszali się tylko Chińczycy i Rosjanie, co zaniepokoiło tamtejsze władze. Podobne zaskoczenie przeżyli włodarze łotewscy, gdyż oczekiwali przyjazdu migrantów z całego świata, a zareagowało na ich ofertę 7 tys. Rosjan.Wyjątkiem w tym materialistycznym werbunku była gwiazda opery rosyjskiej, która otrzymała obywatelstwo „za wniesione już 
i oczekiwane nadal nadzwyczajne osiągnięcia w specjalnym interesie Republiki Austriackiej“. Przedstawiciel organizacji „Pro Azyl“ uznał z kolei, że „uchodźcy z Syrii topią się w Morzu Śródziemnym, a bogaci mogą do nas przyjeżdżać niezależnie od źródła pochodzenia ich pieniędzy”. W ten sposób kupione narodowe obywatelstwo otwiera drzwi do UE i związane z unijnym obywatelstwem prawa. Komisja UE jest oczywiście zaskoczona takimi praktykami i „będzie sprawdzać, czy odpowiada ona europejskiemu prawu i wartościom“, chociaż jeden z parlamentarzystów UE wydał już swoją opinię: „Sprzedaż obywatelstw jest niesolidarna i ponadto stanowi zachętę dla zorganizowanej przęstępczości, zwłaszcza w praniu pieniędzy“.

\section{Sytuacja uchodźców w krajach sąsiedzkich UE}

Prawne odgraniczanie uchodźców i utrzymywanie w południowych i wschodnich krajach UE oraz sąsiednich krajach nienależących do UE doprowadziło do tego, że żyje ich tam (w 2012) już setki tysięcy. W krajach sąsiednich UE zarejestrowano 530 tys. uchodźców i przypuszcza się egzystencję ponad $1 \mathrm{mln}$ nieregularnych migrantów (wiekszość w Turcji). W granicznych panstwach UE zarejestrowano 182043 uchodźców i szacuje się obecność 1,4 do 1,6 mln migrantów nieregularnych. Ponieważ kraje nienależące do UE często nie mają jeszcze dobrze funkcjonujących systemów postępowania azylowego, uchodźcy nie dysponują zezwoleniami na pobyt i mieszają się po prostu z migrantami nieregularnymi, oczekującymi latami na obywatelstwo bądź pozwolenie na wyjazd do innych krajów. Ich status jest nie do pozazdroszczenia, ponieważ nie mają praw obywatelskich i ich los zależy od dobrej woli władz i ludności danego kraju. Migranci z krajów sąsiedzkich UE starają się co roku wjechać do wybranego kraju UE, ale jest to coraz trudniejsze. W roku 2008 udało się to 151 tys. osób, a w roku 2012 jedynie 73 tys. Szacuje się, że w krajach tych na emigrację do UE czeka i przygotowuje się jeszcze 2 do 2,6 mln osób (nie licząc potencjalnch emigrantów z Rosji).

W krajach sąsiadujących $z$ UE panuje skomplikowana sytuacja prawna. Turcja przyznaje azyl tylko uchodźcom europejskim, inni migranci, po długotrwałej procedurze uznaniowej, zmuszani są wyjeżdżać do innych krajów, głównie do Stanów Zjednoczonych. W kraju tym funkcjonują równolegle dwa systemy, państwowy i ONZ (UNHCR), a rezultaty ich działania są niejednokrotnie sprzeczne. Migranci wnioskujący o azyl roz- 
mieszczeni są w 51 tzw. satelitarnych miastach, gdzie zdani są właściwie na siebie samych, bez wystarczających na byt świadczeń, ale mają dostęp do służby zdrowia. W roku 2013 Turcja przyjęła jednakże ponad 200 tys. uciekinierów z ogarniętej wojną domową Syrii i zapewniła im pobyt w 17 obozach z wyżywieniem, pomocą medyczną i możliwością edukacji. Na Ukrainie system przeprowadzenia postępowania azylowego był do roku 2011 zupełnie dysfunkcjonalny. Dopiero w roku 2013 wydano ustawę, która ma tę sytuację zmienić. Migranci złapani na nielegalnym przekroczeniu granicy są tu po prostu aresztowani i traktowani jak więźniowie zgrupowani w obozach finansowanych przez Unią Europejską. Areszt trwa przeciętnie do 12 miesięcy, a dla uciekinierów-recydywistów do kilku lat. Dla 8 tys. uchodźców w roku 2013 przeznaczono zaledwie trzy obozy łącznie z 300 miejscami zakwaterowania. Zaopatrzenie migrantów, poza obozem we Lwowie, którym opiekuję sie zakon jezuicki, jest bardzo ograniczone. Agencja ONZ (UNHCR) płaci każdemu migrantowi 50 dolarów miesięcznie, ale wystarcza to zaledwie na pokrycie czynszu w wieloosobowym pokoju. Dostęp do służby zdrowia widnieje raczej na papierze niż w rzeczywistości. Podobnie jest w Serbii, gdzie urząd do spraw azylu praktycznie nie działa, gdyż zatrudnia za mało pracowników. W Libii i Maroku nie ma narodowych systemów azylowych, a dostęp do przedstawicielstwa UNHCR jest utrudniony lub wręcz niemożliwy. Libijska niepaństwowa milicja więzi uchodźców w okropnych warunkach. Analogicznie dzieje się w Maroku, gdzie wobec braku obozów, aresztowanych przetrzymuje się w nieprzystosowanych do tego celu stacjach policyjnych.Eksperci i osoby, które mają za sobą procedurę przyznawania statusu azylanta, krytykują sytuację uchodźców w tych krajach, twierdząc, że aresztowani nie mają żadnego dostępu do adwokatów i są pozbawieni prawa do odwołań od decyzji urzędów, nie otrzymują wystarczających środków do życia, warunki higieniczne w obozach są karastrofalne; nie zezwala się im na wyjście i nie mają żadnych możliwości podjęcia pracy. Często ich warunki pobytu w obozach są gorsze niż przestępców w więzieniach. $Z$ reguły traktowani są jak aresztowani kryminaliści, co jest sprzeczne z artykułem 31 Konwencji Uchodźców Organizacji Narodów Zjednoczonych. We wszystkich tu wymienionych państwach, migrantom odmawia się ochrony prawnej, nie wystawia się choćby tymczasowych dokumentów osobistych, co oznacza, że pozostają w stanie nieregularności, zdani na samowolę policji lub służb o trudnej do zidentyfikowania podległości. Bywa, że już na granicy odmawia się migrantom prawa do jej przejścia i bezpośrednio wydala do państwa, gdzie trwa np. wojna lub można być prześladowanym. 
Tabela 1. Uchodźcy i nieregularni migranci w krajach przygranicznych Unii Europejskiej w roku 2013 lub w latach wcześniejszych

\begin{tabular}{|c|c|c|c|}
\hline $\begin{array}{l}\text { W UE lub } \\
\text { poza }\end{array}$ & Państwa & $\begin{array}{l}\text { Wnioskujący } \\
\text { o azyl uchodźcy }\end{array}$ & Nieregularni migranci* \\
\hline \multirow{6}{*}{ 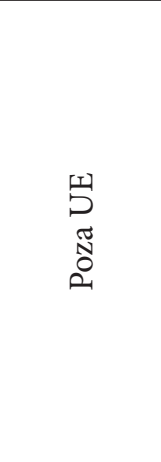 } & Maroko & 2992 & 10000 z Afryki Subsaharyjskiej \\
\hline & Tunezja & 1775 & kilka tysięcy \\
\hline & Libia & 13617 & $1,5 \mathrm{mln}$ \\
\hline & Turcja & $\begin{array}{c}33000+400000 \\
\text { z Syrii }\end{array}$ & $\begin{array}{c}\text { 0,5 - 1,0 mln, w tym dziesiątki tys. } \\
\text { z Afganistanu, Iraku i Iranu }\end{array}$ \\
\hline & Serbia & $\begin{array}{c}3100+66 \\
370 \text { z krajów } \\
\text { sąsiedzkich }\end{array}$ & $\begin{array}{c}18000 \text { (nielegalne przeszło granice } \\
\text { w 2012) }\end{array}$ \\
\hline & Ukraina & 7889 & $11300(\mathrm{w} 2008)$ \\
\hline \multirow{11}{*}{$\begin{array}{l}5 \\
3 \\
3\end{array}$} & Hiszpania & 8300 & $300000-390000$ (w 2009) \\
\hline & Włochy & 79100 & $651000($ w 2008) \\
\hline & Malta & 9015 & 2000 \\
\hline & Grecja & 38283 & $350000(\mathrm{w} 2011)$ \\
\hline & Cypr & 6267 & $15000-20000$ \\
\hline & Bulgaria & 3558 & $3000-4000$ \\
\hline & Węgry & 4440 & $10000-50000(\mathrm{w} 2007)$ \\
\hline & Słowacja & 856 & $15000-20000($ w 2007) \\
\hline & Polska & 19001 & $40000-100000(w 2011)$ \\
\hline & $\begin{array}{l}\text { Estonia, Litwa, } \\
\text { Łotwa }\end{array}$ & 1414 & $10000-38000$ \\
\hline & Finlandia & 11800 & $8000-12000$ \\
\hline
\end{tabular}

* Dane, przedstawione przez odpowiednie urzędy pństwowe, dotyczące liczby migrantów nieregularnych są szacunkowe (nie zawsze aktualne).

Źródło: UNHCR; Irregular Migration Net i Fundamental Right Agency.

Innym zjawiskiem jest wszechogarniająca, szczególnie w Libii i na Ukrainie, korupcja. Aby złożyć wniosek o azyl do ukraińskiego urzędu, być zwolnionym $\mathrm{z}$ aresztu, otrzymać paszport uchodźcy lub nie być zatrzymanym przez policję na ulicy, należy dać urzędnikowi, policjantowi czy tłumaczowi odpowiednią łapówkę,

Do dramatycznych sytuacji dochodzi w Maroku i Serbii, gdzie tysiące migrantów narażonych jest na bezdomność, gdyż brakuje tam po pro- 
stu miejsc w prowizorycznych obozach. Migranci budują sobie, najczęściej wokół obozów i na opłotkach miasta, dachy nad głowami z plastiku, kartonów i drzew. Co pewien czas są one (np. w Serbii) spalane przez policję w ramach programu „walki z nielegalną migracją". W wielu krajach migranci są narażeni na różne czyny przestępcze i gwałty. Wykonują je notorycznie policjanci (Maroko, Libia i Ukraina), kryminaliści (Maroko, Libia i Turcja) oraz rasiści (Ukraina). Szczególnie kobiety są ofiarami seksualnych gwałtów, praktykowanych przez policjantów w Libii oraz kryminalistów i okoliczną ludność w Maroku i Turcji. Na przykład, według danych UNHCR, 43\% wszystkich migrantów, którzy przechodzili przez Maroko było ofiarami gwałtu, a 36\% wszystkich kobiet zostało ofiarami gwałtu seksualnego,

Wniosek $\mathrm{z}$ tej sytuacji jest jednoznaczny. Niemal we wszystkich krajach sąsiadujących z UE stosowanie systemu azylowego i przyjmowanie migrantów nie spełnia międzynarodowych norm. Wszelkiego rodzaju migranci nie są w tych krajach przez długi czas ani bezpieczni, ani nie znajdują warunków dla godnego ludzi życia.

\section{Rozważania o kulturze przyjmownia}

Kogoś chętnie przywitać, to wyrazić i dać poznać, że przychodząca osoba jest oczekiwana i mile widziana. Kulturowe różnice mogą jednakże na wstępie spotkania osoby z innego kręgu kulturowego zakłócić takie intencje [Bartz 2011: 15-28]. Kultura przyjmowania (KP) jest stosowana w debatach politycznych i gospodarczych oraz prezentowana w mediach, czy też dążeniach niektórych urzędów publicznych w formie „otwarcia“ dla zainteresowanych. Z żądaniem o więcej KP można także kojarzyć osiąganie celu podniesienia atrakcyjności danego kraju czy regionu dla wzmożenia zjawiska imigracji. Trend ten jest znany z klasycznych krajów imigracji i polega na ułatwianiu formalności związanych z przyjazdem i pobytem, czyli np. z zmeldowaniem się i przyznawaniem statusu obywatelskiego i zawodowego. Ważne są tutaj metody werbowania fachowców za granicą i regulacje dotyczące bezproblemowego dotarcia, tudzież prawnego usankcjonowania długookresowego pobytu, łącznie z perspektywą stałej pracy oraz życzliwych kontaktów z urzędnikami i ludnością tubylczą. O ułatwieniu tego rodzaju koniecznych formalności, potencjalni imigranci powinni być poinformowani jeszcze przed decyzją o emigracji. W każdym razie osoby zamierzające emigrować nie mogą się obawiać, że rezultat kontaktów 
z urzędami wybranego kraju mógłby być dla nich negatywny. Odwrotnie, przez jasne określenie warunków procedury przyjmowania, przyszli emigranci powinni zdobyć przekonanie, że w nowym kraju będą witani z niewymuszoną chęcią, gdyż przyczyniają się do zachowania lub nawet przyrostu jego poziomu dobrobytu.

Kultura przyjmowania migrantów może być również rozumiana jako specjalny aspekt obchodzenia się z różnorodnością członków społeczeństwa. Ukazuje ona, w jaki sposób traktuje się innych, nowo przybyłych ludzi z nieznaną tożsamością i pozytywnymi intencjami pracy dla siebie i dobra ogółu. Upowszechnienie adekwatnej KP i zastosowanie koncepcji zarządzania opartej na wykorzystaniu synergetycznego efektu tkwiącego w wielokulturowości zatrudnionych pracowników (Diversity Management) w urzędach rozpatrujących sprawy obcokrajowców i podmiotach gospodarczych może doprowadzić do uwrażliwienia załóg na obchodzenie się z różnorodnością i wyzwolenia nierozpoznanego jeszcze potencjału migrantów.

W Niemczech rozpoczęto $w$ ostatnich latach intensywną debatę o KP w związku z faktem przyśpieszonego, demograficznego starzenia się społeczeństwa i znacznego niedosytu fachowych pracowników. Przewiduje się, że w roku 2030 w Niemczech będzie żyło jedynie 74,7 mln osób (dziś około $82 \mathrm{mln}$ ), w tej liczbie 16,9\% będą stanowili młodsi niż 20-letni i 35,4\% starsi niż 60-letni. Bez dopływu odpowiedniej liczby imigrantów w wieku produkcyjnym, nie będzie można wykorzystać potencjału gospodarczego i zabezpieczyć socjalnego standardu emerytowanej ludności. Kraj ten nie zawsze może liczyć na wystarczającą liczbę imigrantów ( a potrzebuje ich rocznie w granicach 150-200 tys. rocznie). Tym bardziej, że nie jest jedynym krajem OECD, który systematycznie werbuje niezbędne siły robocze. Dlatego planuje nadal aktywnie uczestniczyć w międzynarodowej konkurencji o przyciąganie pracowników, co implikuje skuteczne uatrakcyjnienie przyjazdu i pobytu. Na przykład w roku 2013, na wyraźne zapotrzebownie zjednoczeń gospodarczych, wprowadzono w życie dyrektywy UE w sprawie traktowania obcokrajowców ze specyficznymi kwalifikacjami zawodowymi (w postaci ustawy o uznawaniu wykształcenia zawodowego i nowego rozporządzenia o zatrudnieniu). Rozporządzenie to reguluje kwestie przyjazdu sił roboczych bez wyksztalcenia akademickiego, ale z wyuczonym zawodem, z tzw. krajów trzecich (spoza UE). Warunkiem dla imigracji jest jednakże posiadanie takiego świadectwa ukończenia szkoły, które byłoby równowartościowe $\mathrm{z}$ niemieckim wykztałceniem zawodowym. Sporządzenie analizy zapotrzebowania w podziale na zainteresowa- 
ne branże i regiony oraz specyfikację pożądanych zawodów powierzono Federalnej Agencji Pracy, czyli korporacji zrzeszającej i koordynującej wszystkie lokalne agencje i urzędy pracy. Dla potencjalnych imigrantów z wyższym wykształceniem wprowadzono „zielone karty“, których nabycie jest uwarunkowane dysponowaniem dyplomem wyższj uczelni i ofertą wynagrodzenia rocznego ze strony werbującego pracodawcy w wysokości nie mniejszej aniżeli 45 tys. euro [Bundesregierung... 2013].

Tak przedstawiają się nowe założenia KP, sprzyjające selektywnej imigracji nowych aktów prawnych. W praktyce wygląda to zupełnie inaczej. W dyskursie przedstawicieli gospodarki i badaczy naukowych docenia się, że Niemcy, jako państwo nastawione na eksport, podjęło ostatnio liczne starania o wspieranie KP, ale w życiu codziennym trudno jej doświadczyć. $\mathrm{Z}$ poczynionych badań wynika, że w sferze urzędniczego obchodzenia się $\mathrm{z}$ osobami kulturowo innymi, obserwuje się wiele form dyskryminacji. Migranci odczuwają w kontaktach z instytucjami zajmującymi się gospodarką mieszkaniową, edukacją czy rynkiem pracy, że są krzywdzeni [SVR 2012]. Zwerbowni przez firmy bawarskie absolwenci wyższych uczelni z Indii, po wizytach w urzędzie dla obcokrajowców, zaznali wiele różnych zachowań, oprócz oczekiwanej kultury powitania. Potwierdzają to także studiujący akademicy, iż po odwiedzinach w urzędach czuli się często sfrustrowani i niepożądani, co ostatecznie wpływało na ich obraz tego kraju. O tym, że dyskryminacja jest cechą rzeczywistości niemieckiej w wielu obszarach życia donosi ponadto Pełnomocnik Rządu RFN do spraw Antydyskryminacji [Antidiskriminierungsstelle 2013], podając zarazem przedsięwzięcia służące jej zwalczaniu.

Interpretując te informacje o rażącej niekonsekwencji, można stwierdzić, że wprawdzie KP w wielu obszarach życia nie jest obecna, ale perspektywa zmian zaznaczyła się wyraźnie. W polityce i mediach traktuje się zwerbowane siły robocze jako nieodzowne zasoby żywej pracy, a nie jako zagrożenie dla bezrobotnej ludności i obciążanie dla funduszu świadczeń socjalnych. Ponadto, pracujący imigranci zaliczają się stopniowo do głównych zainteresowań opinii publicznej, stymulując duże odłamy przyjmującego społeczeństwa do lepszego obchodzenia się z różnorodnością innych. I jest to najwyższy czas, gdyż dotychczas przede wszystkim analizowano, prześwietlano i oceniano (często z dużą dozą uprzedzeń i stygmatów) wyłącznie nowo przybywających do „szpiku kości” i „szklanej przejrzystości”, pozostawiając postawę i stosunek ludności tubylczej i obsługujących urzędników w bezkrytycznej sferze tabu. Ta dysproporcja w traktowaniu wielokulturowych migrantów i brak przygotowania społeczeństwa do ich 
odpowiedniego przyjęcia okazała zasadniczą przeszkodą w pomyślnym przebiegu integracji. Pierwszy masowy werbunek tzw. gastarbeiterów (robotników gości) w latach 1952-1965 dobrze charakteryzuje obiegowe powiedzenie: „werbowaliśmy siły robocze, a przyjechali ludzie“, jako że robotnicy z Turcji sprowadzali całe rodziny, a do integracji ich żon i licznych dzieci powojenne Niemcy nie były przygotowane. Potem nastapił długi i trudny okres nieudanej w dużym stopniu (głównie z powodu braku woli politycznej i poczucia zagrożenia tożsamości narodowej i kulturowej rodzimej ludności) integracji imigrantów do społeczeństwa niemieckiego. Napisałem długi okres, gdyż trwający praktycznie do 2005 roku, kiedy RFN uznała siebie za kraj imigracyjny, chociaż postępy w integracji były niejednolite, co oznacza, że w niektórych landach i miastach integracja przebiegała przyzwoicie. Podkreśliłem też okres trudny, ponieważ efekty tego procesu są wysoce niezadowalające. Wystarczy podać, że:

- udział młodych dorosłych (25-34 lat) bez wykształcenia zawodowego lub ukończenia szkoły wyższej maleje, ale wśród młodych dorosłych z tłem migracyjnym jest 3-krotnie wyższy;

- ryzyko zostania biednym kształtowało się u ludności niemieckiej w roku 2010 na poziomie 14,5\%, a wśród ludności z pochodzeniem migracyjnym na poziomie 26,2\% [Beuftragte 2012: 86];

- rodziny migrantów są dwa razy częściej uzależnione od pomocy socjalnej niż rodzima ludność niemiecka [Bundesministerium 2009: $12]$

- bezrobotni z tłem migracyjnym przeważają: wśród 20\% ludności niemieckiej z pochodzeniem migracyjnym aż 35\% w roku 2012 stanowili bezrobotnych [Bundesagentur 2013].

Co wobec takiej sytuacji myślą uchodźcy i migranci o docelowo wybranym państwie?

- $\quad$ w opinii publicznej przeważa przeświadczenie, że migranci są w społeczeństwie niechciani i stwarzają problemy;

- rodzime społeczeństwo nie jest poinformowane o znaczeniu i roli migrantów dla ich państwa i obawia się kontaktów z migrantami, gdyż nie jest do nich przygotowane;

- przeważająca liczba migrantów zalicza się do najbiedniejszych warstw społecznych, gdyż wykonują najcięższe i najmniej płatne prace i wychowują przeciętnie więcej dzieci niż ludność rodzima

- na co dzień doświadczają różnorakich form dyskryminacji i odgraniczeń, zwłaszcza w szkole i podczas wykonywania zawodu; 
- prawicowy ekstremizm i rasizm stanowią odczuwalne zagrożenie ich egzystencji i poziomu życia;

- w europejskich krajach z dużym udziałem imigrantów nie rozwinięto jeszcze wspólnego poczucia „my“, niezależnego od etnicznego pochodzenia.

\section{Nowe perspektywy usprawnienia polityki migracyjnej i integracyjnej}

Mimo pewnych inicjatyw na poziomie ogólnokrajowym polityka ta nie znalazła jeszcze pełnego uznania politycznego i nie opracowano jej całościowej koncepcji. Tymczasem różne jej obszary są kluczowe dla rozwoju demokracji, zabezpiecznia dobrobytu i uczestnictwa kraju w przezwyciężaniu międzynarodowych wyzwań. Dlatego, bazując na zebranym doświadczeniu i badniach naukowych, nieodzowne są następujące zmiany perspektyw [Filsinger 2013: 8-25]:

1. Zmiana perspektywy:

Nowe rozumienie integracji

Szeroko rozumiana integracja $\mathrm{w}$ nowoczesnym i heterogenicznym społeczeństwie obejmuje wzystkie grupy społeczne, nie tylko migrantów i nie ogranicza się wyłącznie do aspektów etnicznych, kulturowych i religijnych. Nie ma integracji do społeczeństwa, istnieje natomiast do pojedynczych sfer życia, instytucji i miejscowości, w których współżycie udaje się lub nie i gdzie drogi dostępu są otwarte lub zamknięte. Celem polityki integracyjnej jest likwidacja lub redukcja społecznej nierówności i realizacja sprawiedliwości społecznej. Rasistowskie myślenie należy wykryć i zwalczyć. By uniknąć wykluczeń i odgraniczeń, konieczny jest staranny i refleksyjny stosunek do używanych powszechnie pojęć. Zaleca się stosowanie, zamiast innych, takich słów jak: „migrant“, „migrantka“, „rodzina migracyjna“.

2. Zmiana perspektywy:

Rząd, ministerstwa i podległe im urzędy funkcjonują interkulturowo

Odtąd zwracający się do nich migranci nie powinni mieć problemów i trudności. Przy czym, to interkulturowe otwarcie należy 
rozumieć jako strategiczny, systematyczny, wymagający czasu i nakładów proces dalszego rozwoju polityk wszelkich resortów i odpowiedzialnego za całość rządu. Decydujące znaczenie ma to,że cały ten proces musi być „chciany od góry” i „niesiony od dołu”. Sprawy wynikające $\mathrm{z}$ interkulturowego otwarcia muszą podlegać szefowi, czyli naczelnemu kierownictwu każdej instytucji lub struktury. Wszystkie inicjatywy ustawowe powinny być badane pod kątem ich oddziaływania na zmniejszanie nierówności społecznych. Interkulturowe zarządzanie personelem (Diversity Mangement) i wyodrębnienie budżetu dla obsługi migrantów powinno być stałą regułą. Potrzebne jest sformułowanie nowego wzorca tożsamości obywatela imigracyjnego kraju, który pozwoli z czasem na przezwyciężenie podziału społeczeństwa na „swoich“ i „tamtych“. Wreszcie należy rozwinąć praktykownie poddawania się opinii petentów i permanentne doskonalenie działania. Temu celowi służy stosowanie ewaluacji i monitoring procesu integracji oparty na obserwacji realizacji sformułowanych wskaźników.

3. Zmiana perspektywy:

Kształtowanie koherentnej polityki migracyjnej

Ponieważ w przyszłości, z powodów gospodarczych, niemal każde państwo europejskie zdane będzie na przyjmowanie migrantów, dla złagodzenia następstw ujemnego trendu demograficznego ukształtowanie adekwatnej do potrzeb polityki migracyjnej jest niczym niezastępowalne. Stąd, oprócz wdrażania interkulturowego otwarcia sensowne jest wprowadzenie (wzorem klasycznych krajów imigracyjnych) systemu punktowego, jako instrumentu korzystnego sterowania ruchem migracyjnym. Wewnątrz kraju konieczne jest zorganizowanie kampanii wyjaśniającej na rzecz pozytywnej roli i wizerunku migrantów. Poza granicami natomiast prezentujemy się jako wiarygodny kraj imigracyjny. Znając współzależność migracji od sytuacji w karajach emigracyjnych, należy połączyć lub skoordynować politykę migracyjną z polityką pomocy dla krajów rozwijających się. W związku z prawem wolnego ruchu osobowego i osiedlania się w ramach UE nie można dopuścić do tworzenia się Europy dwóch klas społecznych, a migracja nie powinna prowadzić do upowszechniania dampingowych wynagrodzeń, niebezpiecznych warunków pracy i wypierania zasiedziałych grup społecznych. 
Zmiana perspektywy:

Zorientowanie ochrony uchodźców i praw do pobytu na jak najszybszy udział w życiu społecznym

Dotychczas status pobytu większości uchodźców pozostawał przez lata niepewny, chociaż starają się oni umacniać swoją rolę wszelkimi sposobami, nawet w warunkach obozowych. Od praktyki tej trzeba zdecydowanie odstąpić przez przedstawienie konkretnej oferty integracyjnej i zaprzestanie ograniczania mobilności przestrzennej. Pomoc socjalna powinna pokrywać realne potrzeby, a obozy dla uchodźców w przewidywalnym czasie powinny być likwidowane na korzyść normalnych lokali mieszkalnych. Oferta integracyjna dla dorosłych musi zawierać naukę języka i edukację zawodową, a po ich finalizacji, wspólne z miejscową administracją i pracodawcami planowanie zatrudnienia zawodowego i aktywności społecznej. $\mathrm{Na}$ forum odpowiednich organów UE konieczne jest szybkie ustalenie podziału solidarnej odpowiedzialności poszczególnych państw członkowskich za przyjmowanie uchodźców i innych nieregularnych migrantów oraz odejście od nieproporcjonalnego obciążanie tym zadaniem głównie państw leżących przy granicy zewnętrznej Unii Europejskiej.

\section{Bibliografia}

Alscher S. (2013), Welt-Migrationsrichtung entscheidet ueber subjektives Wohlbefinden, „Migration und Bevoelkerung” nr 8, www.bpb.de/gessellschaft/migration/dossier migration [22.10.2013]

Antidiskriminierungsstelle des Bundes (2013), Diskriminierung in Bildingsbereich und Arbeitsleben, Berlin

Bartz B. (2011), Kulturowe różnice i warunki interkulturowego porozumienia, „Drohiczyński Przegląd Naukowy" nr 3

Beuftragte der Bundesregierung fuer Migration (2012), Fluechtlinge und Integration, 2 Integrationsindikatorenbericht, Berlin

Brinkbaeumer K. (2006), Welt der Wandernden und die afrikanische Odyssee, „Der Spiegel" $\mathrm{nr} 26$

Bruegmann M. i in. (2014), Singen fuer Staatsbuergerschaft, „Handelsblatt” nr 12

Bundesagentur fuer Arbeit (2013), Menschen mit Migrationshintergrund auf dem deutschen Markt, Nuernberg

Bundesregierung (2013), Zuwanderung von Facharbeitern erleichtern, Berlin 
Bundesministerium fuer Arbeit und Soziales (2009), Wirkungen des SGB III auf Personen mit Migrtionshinter-grund, Berlin

Council for Parliament of the World Religions (1993), Chicago

European Council for Refuges and Exiles: Welkome to Europe, Bruessel (2012), www. resettlement.eu/files/ICM\%20

Filsinger D. (2013), Perpektivwenwechsel in der Einwanderungsgesellschaft Deutschland. Grundlagen fuer eine neue Miigrations- und Integrationspolitik, www.fes.de/wiso, Bonn

SVR (2012), Benachteiligungserfahrungen von Personen mit und ohne Migrationsgrund, Berlin

Theisen H. (2009), Weltordnung der Kulturen, „Mut” nr 497

The World Bank (2006), Global Economic Prospects. Economic Implications of Remittances and Migrations, Washington 


\section{SUMMARY}

\section{The situation of European immigration policy (the culture of acceptance and inclusion of immigrants in EU)}

European immigration policy is a complex and dynamic field of science with interdisciplinary profile. It is based on humanitarian rights and international regulations concerning immigration and development of humanity. Unfortunately, the dynamics of migration in global and European scale, especially the inflow of immigrants, (according to ONZ - irregular immigrants) has reached in EU levels which make effective integration impossible. Europe needs immigrants but is unable to assimilate them. The author describes similar situations in EU and in neighbouring countries. Immigration policy focused on securing boarders against illegal immigrants is considered to be inhumane and generates criminal behaviours. Later chance for integration is extremely difficult.

\section{Keywords:}

the culture of accepting immigrants, integration, inclusion, exclusion, ethnic group, cultural and national, the significance of migration movement 